\title{
Cyberloafing as a mediating variable in the relationship between workload and organizational
} commitment

\author{
Mohammad Abdallah Aladwan ${ }^{a}$ Imad Al Mualab and Hayatul Safrah Salleh ${ }^{a^{*}}$
}

${ }^{a}$ Faculty of Business, Economics and Social Development, Universiti Malaysia Terengganu, 21030 Kuala Nerus, Terengganu, Malaysia ${ }^{b}$ Faculty of Business, Amman Arab University, Amman, Jordan

\section{H R O N I C L E \\ A B S T R A C T}

Article history:
Received: June 20, 2020
Received in revised format:
August 302020
Accepted: September 18, 2020
Available online:
September 23, 2020
Keywords:
Cyberloafing
Organizational Commitment
Psychological Workload
Physical Workload

\section{Introduction}

Organizations seek to create a healthy work environment and connect employees physically and psychologically, ensuring that the organization's values are accepted and believed in it. The commitment of employees reflects on the quality of their performance and contribution to achieve the goals of the organization efficiently and effectively, so the most pressing motivational issues in any organization are an organizational commitment. Organizational commitment happens not only by reducing absenteeism and delays but also by renewing individual and corporate performance at the same time; therefore, attention to the physical and mental health of the organization's staff is essential and affects the work environment to a large extent. At the forefront of these factors is the stress associated with the functional and organizational context, where the workload is one of the most critical elements of functional stress (Alipour \& Monfared, 2014). There is an increased interest by researchers to focus on studying the workload, as studies have shown that workload affects organizational commitment and leads to employees evading their work and duties (Andersen et al., 2016; Svedberg, 2018). Previous studies showed that other factors also contribute to the evasion of workers' duties, namely cyberloafing, by using the ease of access to various IT devices such as computers, tablets, smartphones as well as widespread internet services. Cyberloafing is the act of employees who use the internet access during working hours for personal use while pretending to do their legitimate work (Kim \& Byrne, 2011; Lim \& Chen, 2012; Sawitri, 2012). Thus, the purpose of this study is to examine the effect of cyberloafing as a mediator on the relationship between workload variables (psychological workload and physical workload) and organizational commitment among employees of mining company in Jordan.

\footnotetext{
* Corresponding author. Tel: +60 96684174

E-mail address: hayatul@umt.edu.my (H. S. Salleh) 


\section{Literature review}

\subsection{Organizational Commitment}

Organizational commitment is one of the topics that has received clear management attention in recent decades, as it relates to organizational effectiveness and degree of completion. Organizational commitment reflects an individual's attitude towards the organization and includes a strong desire to stay in the organization, whereas individuals committed to their organizations are a source of strength to help sustain and compete with other organizations (Jain et al., 2013). The concepts of organizational commitment have varied due to the differing visions of researchers around it, but the clarification of the idea has been complicated by the focus on commitment to the working environment. It includes several areas such as commitment to work, commitment to duties, internal tasks for work, and commitment to the working group, which expressed fundamental variables in organizational commitment. Organizational commitment is a psychological and social condition that indicates the objectives of the employees are consistent with the goals of the organization, have a strong sense of belonging, defending, and the desire to continue with the organization (Al-hawajreh, 2012). In this study, three dimensions of organizational commitment were explored, which is an organizational emotional commitment, normative organizational commitment, and organizational continuance commitment.

\subsubsection{Organizational emotional commitment (OEC)}

Organizational emotional commitment (EOC) is built when the employee feels a secure emotional attachment to the organization, the task that they do, and want to be there. OEC is influenced by the degree of an individual's perception of the characteristics that characterize his/her work. This aspect of commitment is also affected by the degree to which an individual feels the organizational environment in which he operates, allowing him to work according to self-evaluation of the requirements imposed by the different working conditions. The emotional commitment is due to a person's sense of belonging and psychological attachment to the organization. Besides, employees who enjoy their work will be expected to feel happy, and be satisfied with their job and organization. Thus, it will increase job satisfaction as well as job commitment (Niaei et al., 2014).

\subsubsection{Organizational normative commitment (ONC)}

Organizational normative commitment (ONC) is a mindset that one should pursue a course of action related to a specific goal, and the individual's sense that he/she should remain in the organization and support for change (Herscovitch \&Meyer, 2002). ONC happens when the employees feel the organization's excellent support for its employees, which allows them to participate and interact positively, not only in work implementation procedures but also by contributing to the development of the goals, planning and policy-making of the organization. The standard obligation generally increases for employees who work by the requirements of conscience and public interest especially when they are loyal to the employer or feel responsible for the work or compensation for the benefits and benefits received from the organization. The commitment component is based on an individual's awareness of their responsibility to the organization. Also, the individuals' commitment to their current organizations tends to increase, since the skills and education not easily be transferred to another organization (Jain et al., 2013; Niaei et al., 2014).

\subsubsection{Organizational continuance commitment (OCC)}

Organizational continuance commitment (OCC) is the extent to which a person needs to stay in the organization, because of the costs and benefits associated with an individual's investments in the organization (Allen \& Meyer, 2000). OCC shows the commitment level of employee to the organization, in terms of how the employee perceived the investment value he/she can achieve if he/she continues to work with the organization, in return for what he/she will lose if he/she decides to join other organization. It is an interesting link, and it depends on the benefit it gets from the organization, as long as the organization offers more advantages than other organizations, the employee will remain. However, for the employee with high ambitions, she/he will not hesitate to move to a new organization if it provides better returns and benefits compare to the current organization (Hashemi et al., 2015).

\subsection{Workload}

There is no doubt that the intensification of work has an impact on employees by increasing the demand for their cognitive, psychological, and physical skills, and it has been observed that some health and safety issues related to work have occurred in various sectors of the work due to workload (Baernholdt et al., 2010). Overall, the common denominator in the psychological and physical outcomes observed in the workers is undoubtedly the workload. The increased workload harms their health and safety at work, such as muscle disorders, psychological distress and fatigue. In light of the continuous and rapid changes occurring within the organizations, the workload issue has become a focus of attention for researchers and concern for organizations (Macphee et al., 2017). The concept of workload is not new, but in the current context of internet-savvy users, it has become a topic of interest to researchers and organizations, and more specifically organizations are looking for effective ways to assess the workload, while many tools measure critical aspects of the workload (Myny et al., 2012). The workload can be defined as the effort, and the interaction exerted physically and mentally related to the performance of a task or group of functions to meet the requirements of their work (Martins et al., 2013; Svedberg, 2018). Therefore, the workload must be dealt with comprehensively, by analysing the overall activity that is seen as a result of a set of factors that interfere in the 
workplace and that lead to the physical and mental costs of the worker. Changes in the workload mean changes in the conditions of work. Thus, it is not only taking into account the work activity, but also the regulatory environment in which the individual operates daily (Adeoti et al., 2017). The workload in this study is dealt with from two angles, where it can be classified into the psychological workload and the physical workload. In addition to these classifications; responsibility, work interruption, doubt, and time pressure are some of the factors that affect and increase the workload of mental and physical work (Hansson et al., 2009).

\subsubsection{Psychological workload}

The phenomenon of stress and the burden of psychological work is one of the relatively recent topics, it is not limited to one of the fields but instead extended to every area in which a person engages in a particular activity (Kalyuga, 2011). The psychological workload is a state of extreme tension due to external factors that put pressure on the individual and generate a state of imbalance and behaviour disorder. Therefore, ignoring psychological influences in the workplace affects self-efficacy and thus leads to wasting the overall human and material resources (Freitas et al., 2014). Among the most important effects of the psychological pressure include feeling anxiety and tension, sadness and depression, boredom and a feeling of low selfesteem, low individual morality, mental stress, anger and frustration, insomnia and rapid arousal, and loss of interest. As a result of the individual's feeling of increasing pressure on him/her at work, this leads to a distraction in thinking, excitement, and lack of focus (Yeh et al., 2019).

\subsubsection{Physical workload}

For workers to become associated with the institution, appropriate conditions must be met, including taking into account the pressures caused by the work, which are often absent in their attention and its results and effects. The pressures are often present in the work environment, which paves the individual, threatens him and affects his association with the organization. One of these pressures is the physical workload that results from the nature of the work (Hansson et al., 2009). The physical workload is defined as the work that requires muscular energy, and it is a measurable part when performing a specific task affected by a group of factors. These factors include the nature of work, training, motivation and environmental factors. Therefore the physical workload can be measured through changes in the function of the body's organs through oxygen consumption rate, rate of heart, air circulation to the lungs, and body temperature (Baljoon et al., 2018). As a result of increased pressure on the worker, some negative adverse effects on the worker and his physical integrity occur. The most important physical diseases that a worker can suffer from work stress include stomach ulcers, heart diseases, diabetes, headache, increased heart rate, and blood pressure (Andersen et al., 2016).

\subsection{Cyberloafing}

Various IT devices like computers, tablets, smartphones, and the internet have become a portion of personal and business life, and have brought great benefits to the world. However, workers in organizations use these facilities for particular purposes during working hours, and one of the most common cases is employees cyberloafing in organizations (Ozler \& Polat, 2012). Due to the expansion in local networks and the global internet, the computer cannot be terminated from working life, so cyberloafing is a common fact in institutions today, as companies have high-speed access channels to the internet and it is necessary for research, implementation and communication (Kim \& Byrne, 2011; Niaei et al., 2014). Cyberloafing refers to employees using the internet through their organizations for personal purposes during working hours, including browsing non-job websites (such as social networks, sports, news), checking and sending personal emails (Rajah \& Lim, 2011). Some researchers assume that cyberloafing is a lost activity and results in empty employment. In contrast, others believe that it is necessary during working hours, and there are positive and negative effects of cyberloafing (Henle \& Blanchard, 2008). From the positive side, engaging in cyberloafing for a short time in non-work tasks has some benefits, including reducing stress and weariness and leading to renewal, which leads to more satisfying and increased creativity for employees. The recreational use of the internet for fun, play, and online shopping gives a boost to creativity, reduces anxiety, encourages experimentation, and increases individual well-being (Jamaluddina et al., 2015). From the negative side, cyberloafing can lead to a significant decrease in productivity in organizations and companies and other adverse effects if the employee performs any illegal activity on the internet that threatens company information, such as spyware and harmful viruses as it is responsible for intellectual property losses, security threats, and to avoid performing its duties which leads to reduced productivity and lost time (Chun \& Bock 2006; Khansa et al., 2017). Thus, the purpose of this study is to examine the effect of cyberloafing as a mediator on the relationship between workload (physical workload and psychological workload) and organizational commitment among employees of a mining company in Jordan.

\subsection{Hypotheses Development}

\subsubsection{Workload and organization commitment}

The workload has been a matter of much scientific research in literature over the past decades. A high level of occupational stress caused by heavy workload is a major threat to the physical and mental health of individuals (Verhaeghe et al., 2008). These have affected the workers' cognitive processes that comprise of memory, recall of knowledge, and interest. This has led to the risk of occupational diseases, increases stress, absenteeism, and most importantly, reduces job performance (Kivimäki \& Kawachi, 2015). These problems must be brought under control to improve living and working conditions. Without 
sufficient resources to meet workload requirements, dissatisfaction will grow, and workers might leave the job (Hayes et al., 2012). There is numerous evidence that workload and occupational stress have an impact on the mental and physical health of workers (Sonnentag \& Frese, 2012). Also, high levels of occupational stress are associated with psychological and physical integrity, job dissatisfaction, absenteeism, stress-related injuries, turnover, and intention to quit the organization (Siu, 2002; Winefield et al.,2003). Most previous studies indicated that stress has effects on employees and organizational outcomes (Hashemi et al., 2015). Leiter and Maslach (2009) found that burnout and emotional exhaustion were the signed of nurses' workloads that leads to an increase in turnover rates among nurses. Also, previous researchers found that the low organisational commitment and illness among employees was due to stress (Viljoen \& Rothmann, 2009) and work pressures in terms of work-life balance, overload, control, aspects of work, and pay (Kowalski et al., 2010). The study conducted by Al-hawajreh (2012) and Syailendra and Soetjipto (2017) also establishes that the relationship between emotional exhaustion with work overload and lack of autonomy leads to decreased in organizational commitment. Green and Savin (2013) study the effect of workload in the healthcare industry and shows that workload is related to absenteeism among nurses, and find that absenteeism is exacerbated on the days when the workload is expected to be higher due to insufficient staffing level. Moreover, a study by Alipour and Monfared (2014) showed that job stress also affects organizational commitment (affective, normative and continuance commitment). Thus, this study hypothesized the following:

H1: There is a significant relationship between physical workload and the organizational commitment among employees. $\mathrm{H} 2$ : There is a significant relationship between psychological workload and organizational commitment among employees.

\subsubsection{Workload and cyberloafing}

Cyberloafing is regarded as one of the methods for coping with stress at work (Eastin et al., 2007; Henle \& Blanchard, 2008; Liberman et al., 2011; Lim \& Chen, 2012; Andreassen et al., 2016; Askew et al., 2014). Job stress occurs when the task designated to an employee outweighs the capabilities to perform the job, which leads to work overload, both psychological and physical workload. If the stress level of an employee is high, he/she will procrastinate at work by indulging in cyberloafing, and cyberloafing correlates with reduced workplace involvement (Liberman et al., 2011). It is also proved that cyberloafing behaviour is a strong effect of job burnout (Aghaz \& Sheikh, 2016). Some researchers (Anandarajan et al., 2011; Coker, 2013; Henle \& Blanchard, 2008) reported that cyberloafing is a strategy that workers use to deal with stress in the workplace. The non-work-related web surfing by the employees was interpreted as a way to avoid stressful situations and get away from difficult tasks (Kim \& Byrne, 2011). Browsing the web at work is a relaxing break for workers and effective in increasing individual performances (Coker, 2013). Also, personal web usage is viewed as a good way for managers to relax and get away from overstressing (Ugrin et al., 2008). Another study suggested that cyberloafing provides an effective barrier against work stress, and has shown that taking periodic breaks from work is vital because these breaks allow employees to recharge their energy level and are necessary to improve work performance (Henle \& Blanchard, 2008; Anandarajan et al., 2011). Wan et al. (2014) found that one of the factors driving employees in committing cyberloafing was related to work pressure and the perception of how superiors gave appreciation and fair treatment in the workplace. When employees feel that they are not being treated well, they tend to engage in cyberloafing behaviours. Previous studies also mention that Internet expertise significantly moderate the effect of overuse on cyberloafing, and employees who experience job stress will tend to use cyberloafing (RuningSawitri, 2012; Tseng, 2011). Another study also found that the employees may likely to perform loafing behaviour as a result of work stress (Şen et al., 2016). Thus, work stress due to workload has a positive effect on employees at a certain level, but it may lead to negative results when it goes beyond the acceptable level. Therefore, this study hypothesized the following:

H3: There is a significant relationship between physical workload and the cyberloafing among employees. H4: There is a significant relationship between psychological workload and the cyberloafing among employees.

\subsubsection{Cyberloafing and organization commitment}

There are limited studies examined the relationship between cyberloafing behaviour and organizational commitment among employees (Lee et al., 2000; Zhang \& Zheng, 2009; Piotrowski, 2012). Generally, employees who perceive their organization as not fair is more likely to perform cyberloafing, possibly as a way to retaliate against the injustice. It is suggested that employees who are effectively or normatively committed are more likely to perceive their organization as fair, and therefore less likely to cyberloafing (Lim \& Chen, 2012). On the other hand, employees who may be more susceptible to work stress will try to reduce stress through cyberloafing, and this may affect their organizational commitment (Henle \& Blanchard, 2008). Understanding the relationship between cyberloafing and organizational commitment could provide an insight as to what variables affect work commitment, and that can be used as a predictor for employees exhibiting cyberloafing behaviours.

Individuals who are more committed to their work should be less likely to engage in personal Internet activities on the job (Garrett \& Danziger, 2008). The results show that by allowing employees to take a break from work by cyberloafing is likely to have a positive impact on work performance, and employees feel that surfing the net while working in general, is an enjoyable activity that makes the work more attractive (Lim \& Chen, 2012). Niaei et al. (2014), indicated that the act of cyberloafing among employees are negatively related to each of the dimensions of organizational commitment in their study. Another study found that affective commitment and normative commitment have negative correlation toward cyberloafing, whereas, continuance commitment has a positive correlation toward cyberloafing (Usman et al., 2019; Sage, 2015). Besides, 
a study by Panaccio and Vandenberghe (2012) reported that employees with high emotional commitment are less likely to do cyberloafing. Thus, this study hypothesized the following:

H5: There is a significant relationship between cyberloafing and organization commitment among employees.

\subsubsection{Cyberloafing mediate the relation between workload and organization commitment}

Employers tend to consider cyberloafing as a waste of time, but in real life, people do not spend $100 \%$ of their time on work. It is suggested that cyberloafing can help workers cope with work stress, because when there is the pressure at work, employees surfed the Internet for non-business purposes, and this reduces the intensity and pressure of work (Henle \& Blanchard, 2008). Sawitri (2012) mentioned that cyberloafing is one of many ways for the employees to avoid work stress, thus, employees who undergo work stress will tend to engage in cyberloafing. Cahyadin (2012) shows that no matter how strong the employees' commitment to their supervisor, it will not reduce cyberloafing behaviour of the employees. They added that the higher the employee have excess to it, the higher the employees' cyberloafing will be if they have good internet expertise (p. 275-280). Commitment is not only related to most of the employee's psychological and physical consequences, but also with stress, so stress depends on a person's role in assessing the level of commitment. Therefore, an employee who is experiencing stress will engage in cyberloafing behaviour, depending upon how strong is their commitment towards the organization (Henle \& Blancard, 2008). That is why employees who undergo stress due to workload will be engaged in cyberloafing depending upon how much they committed to their direct supervisor and the organization. Therefore, this study hypothesized the following:

H6: There is a significant effect of cyberloafing as a mediator between physical workload and organizational commitment among employees.

H7: There is a significant effect of cyberloafing as a mediator between the psychological workload and organizational commitment among employees.

\subsection{Theoretical Framework}

The following model was developed to express the relationship between variables of the study in light of a review of previous studies and references. Psychological workload and physical workload are the independent variables, cyberloafing as a mediator variable, and organizational commitment as a dependent variable. The framework of the study is shown in Fig. 1.

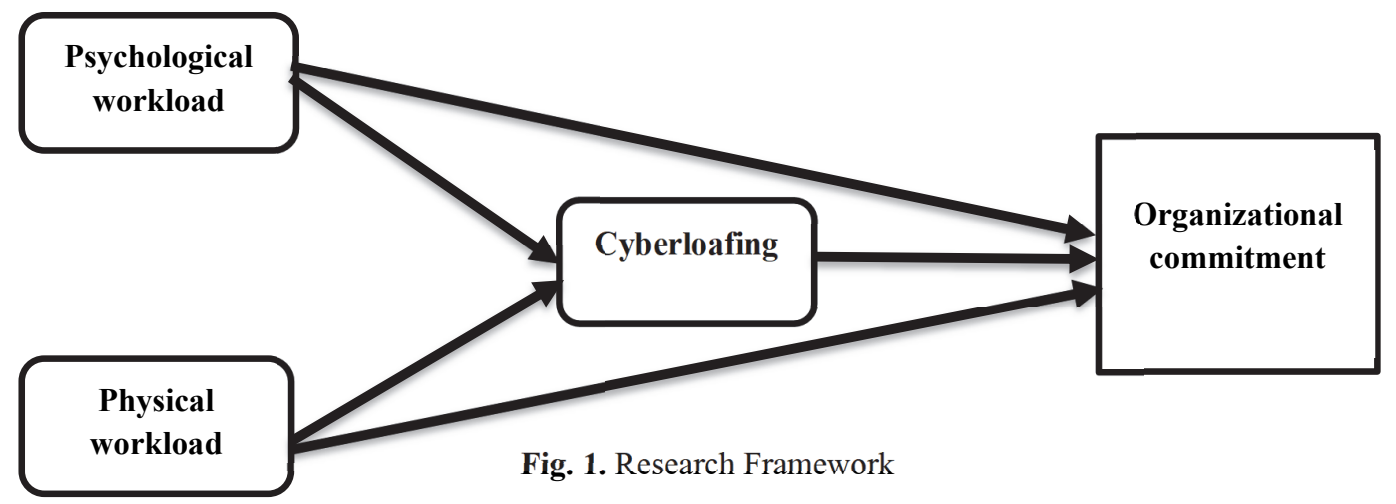

\section{Research methodology}

\subsection{Sample and Data Collection}

The study adopted the descriptive-analytical research approach, as it is appropriate to the nature and objectives of this study. The study population represents the employees of the mining company in Jordan, with a total of 3293 based on the 2018 company's annual report. According to Sekaran (2003), the sample size needed was 351 respondents based on the target population. The study used a convenience sampling method, which the self-administered questionnaire was distributed to 360 employees from the administration department. These employees were selected as a sample because the employees in the administration department are dealing with administrative and paperwork that using the computer and internet. Therefore, when exposed to work stress and tension, their tendency to use cyberloafing is higher than the other department whose work depends on using heavy machine and works that require physical effort, so they have no time to use the internet. A total of 304 questionnaires were usable for analysis, which represented a valid response rate of $84.4 \%$, which is a "very good response rate" based on Babbie (1992, p. 267). Data entry and statistical analysis of reliability and validity of the instruments, descriptive analysis of the demographic profile of the respondents, regression, and testing the mediator effect were conducted using the Statistical Package for Social Science version 23 (SPSS. v23). Data were first checked for missing values and outliers before they were subject to further tests. Factor analysis was run on the main constructs: psychological workload, physical load, cyberloafing, organizational commitment. After factor analysis was performed, reliability, correlation, and multiple regression analyses were tested. 


\subsection{Measurement}

A questionnaire was used to collect data for this study. This questionnaire was developed based on the relevant literature shown in Table 1. The questionnaire was distributed individually to the respondents. The questionnaire included all the constructs' measurement items by using the five-point Likert scale, which expresses the extent of the respondent's agreement with the questionnaire ranging from 1 "strongly disagree" to 5 "strongly agree". In this study, the instruments involving 50 items related to the physical workload, psychological workload, cyberloafing and organization commitment variables of this study. Based on the context of this study, the items were divided into; 4 items for physical workload, 12 items for psychological workload, 11 items for cyberloafing, and 23 items for organization commitment. The measurement items and sources were tabled as in Table 1.

Table 1

Measurement Items and Sources

\begin{tabular}{lll} 
Variable & & \\
Physical & 1. & My work requires kinetic activities related to pushing things continuously. \\
Workload & 2. & My work requires kinetic activities related to pulling things constantly. \\
& 3. & My work requires movement and control activities for long periods. \\
& 4. & My work requires motor activities relating to sitting or standing all the time. \\
\hline Psychological & 1. & My work requires a lot of thinking. \\
Workload & 2. & My work requires a lot of giving decisions. \\
& 3. & My work requires a lot of calculations. \\
& 4. & My work requires a lot of remembrances. \\
& 5. & My work requires a lot of research. \\
& 6. & My work takes a lot of time to finish the tasks. \\
& 7. & My work requires a lot of hard work to finish the tasks. \\
& 8. & Satisfied with my performance level at work. \\
& 9. & I feel my work is safe. \\
10. & I feel my work is encouraging. \\
& 11. & I feel my work is comfortable. \\
12. & I feel my job is right.
\end{tabular}

\begin{tabular}{|c|c|c|}
\hline Cyberloafing & $\begin{array}{l}\text { 1. I surf work offline websites during working hours. } \\
\text { 2. I browse public e-news websites during working hours. } \\
\text { 3. I carry information from websites not connected to work during working hours. } \\
\text { 4. I interact with my friends on social networking sites "Facebook, Twitter, Snapchat, and others". There are } \\
\text { no off-line purposes during working hours. } \\
\text { 5. I browse entertainment websites during working hours. } \\
\text { 7. I browse investment-related websites that have nothing to do with my business during working hours. } \\
\text { 8. I browse sports websites not connected to work during working hours. } \\
\text { 9. I receive a non-business email, during business hours. } \\
\text { 10. I check personal emails during working hours. } \\
\text { 11. I send personal emails during working hours. }\end{array}$ & $\operatorname{Lim}(2002)$ \\
\hline $\begin{array}{l}\text { Organization } \\
\text { Commitment }\end{array}$ & $\begin{array}{l}\text { Emotional Commitment } \\
\text { 1. I would be very happy to spend the rest of my career with this company. } \\
\text { 2. I enjoy discussing my company with people outside of it. } \\
\text { 3. I feel as if this company's problems were my problems. } \\
\text { 4. I think I am associated with another organization just as I am affiliated with this company easily. } \\
\text { 5. I feel "part of the family" in my company. } \\
\text { 6. I feel emotionally attached to this company. } \\
\text { 7. This company has a great deal of personal meaning to me. } \\
\text { 8. I feel a sense of belonging to my company. } \\
\text { Continuance Commitment } \\
\text { 1. I am afraid of what might happen if I quit my job without getting another job. } \\
\text { 2. It will be very difficult for me to leave the company at the moment. } \\
\text { 3. Much of my life will be disrupted if I decide to leave the company now. } \\
\text { 4. It would be too expensive for me to leave the company now. } \\
\text { 5. For the time being, staying with the company is a necessary matter. } \\
\text { 6. I feel I have very few options to consider leaving this company. } \\
\text { 7. One of the dire consequences of leaving this company is the lack of available alternatives. } \\
\text { 8. One of the main reasons for continuing to work in this company is that departure requires a great deal of } \\
\text { Normative Commitment } \\
\text { 1. I think people nowadays often move from one organization to another. } \\
\text { 2. I think a person should always be loyal to his organization. } \\
\text { 3. Moving from one organization to another seems completely unethical. } \\
\text { 4. One of the main reasons I keep working with this doubts is my belief that loyalty matters. } \\
\text { 5. If I get another offer for a better job elsewhere, I will accept that offer. } \\
\text { 6. I think loyalty remains to one organization. } \\
\text { 7. Things are better on the days when people stay in one organization for most of their careers. }\end{array}$ & $\begin{array}{l}\text { Allen and } \\
\text { Meyer } \\
(1990)\end{array}$ \\
\hline
\end{tabular}

\section{Results}

For reliability testing, the Cronbach alpha coefficient was used to assess the internal consistency of the developed tool to ensure that the research instrument is comprehendible by the respondents. It is noted from Table 2 , that the values of internal 
consistency ranged between 0.703 and 0.789 . All of which are acceptable according to (Connelly, 2011; Taber, 2018). Table 3 shows the correlations coefficients of the main variables. As indicated, the instruments that measured the main variables were deemed to be reliable. The correlations between psychological workload, physical load, and organizational commitment showed positive and significant, but the relationship between cyberloafing and organizational commitment was significant and negative.

Table 2

Reliability Analysis

\begin{tabular}{lll}
\hline Variable & Cronbach's Alpha & No. of Items \\
\hline Physical workload & 0.726 & 4 \\
Psychological workload & 0.720 & 12 \\
Cyberloafing & 0.789 & 11 \\
Organization Commitment & 0.703 & 23 \\
\hline
\end{tabular}

Table 3

Correlations Coefficients of Main Variables

\begin{tabular}{|c|c|c|c|c|}
\hline & PSW & PHW & CY & $\mathrm{OC}$ \\
\hline PSW & 1 & & & \\
\hline PHW & $.139 *$ & 1 & & \\
\hline CY & $-.244 *$ & $-.011^{*}$ & 1 & \\
\hline OC & $.548 *$ & $.229 *$ & $-.089 *$ & 1 \\
\hline
\end{tabular}

Note: ** Correlation is significant at the .05 level (2-tailed).

PSW = Psychological workload; PHW = Physical workload CY = Cyberloafing; $\mathrm{OC}=$ organizational commitment

To test the first and second hypotheses, the multiple regression analysis was performed. Before the analysis, the test assumptions were validated. No significant violation of normality, linearity, homoscedasticity, multicollinearity, and independence of errors was found. Based on the multiple regression analysis, Table 4 shows that the relationship between workload (with its dimensions of physical workload and psychological workload) and organizational commitment was significant $\left(\mathrm{R}^{2}=.247\right.$, $\mathrm{F}=49.447, \mathrm{p}<.05)$. However, the model showed a low relationship with workload dimensions explained only $24.7 \%$ of the variation in organizational commitment. Therefore, hypotheses $\mathrm{H} 1$ and $\mathrm{H} 2$ were supported.

Table 4

Results of Multiple Regression Analysis between Workload and Organization Commitment

\begin{tabular}{cccc}
\hline Independent Variables & B & T & \multicolumn{1}{c}{} \\
\hline Physical workload & .146 & 5.789 & 0.026 \\
Psychological workload & .271 & 7.902 & 0.015 \\
\hline
\end{tabular}

$\mathrm{R}^{2}=.247 ; \mathrm{F}=49.447$

To test the third and the fourth hypotheses, the multiple regression analysis was performed. Table 5 displays the results of multiple regression analysis to determine the effect of the workload with its dimensions of physical workload and psychological workload on cyberloafing. The results show that these factors combined have explained only $6.6 \%$ of the variance in cyberloafing $\left(\mathrm{R}^{2}=.066, \mathrm{~F}=9.598, \mathrm{p}<.05\right)$, which demonstrated a very low variance on organizational commitment. Meaning that another $93.4 \%$ of the variance in organizational commitment can be explained by other factors. The results indicated that psychological workload was positively affect cyberloafing behaviour. Whereas, the physical workload has no significant effect on cyberloafing behaviour among employees. Therefore, hypotheses H3 was not supported while hypotheses H4 was supported.

Table 5

Results of Multiple Regression Analysis between Workload and Cyberloafing

\begin{tabular}{cccc}
\hline Independent Variables & B & T & $\boldsymbol{\alpha}$ \\
physical workload & .026 & .417 & .645 \\
psychological workload & -.385 & -4.377 & .000 \\
\hline $\mathrm{R}^{2}=.066 ; \mathrm{F}=9.598$ & &
\end{tabular}

To test hypotheses five, simple linear regression analysis was utilized to determine the effect of cyberloafing on organizational commitment. The result in Table 6 shows that cyberloafing significantly influence organizational commitment and has explained $2.6 \%$ of the variance in organization commitment $\left(\mathrm{R}^{2}=.026, \mathrm{~F}=8.173, \mathrm{p}<.05\right)$. Thus, hypothesis $\mathrm{H} 5$ was supported.

Table 6

The Effect of Cyberloafing on Organizational Commitment

\begin{tabular}{cccc}
\hline Mediate Variables & B & T & $\boldsymbol{\alpha}$ \\
\hline & Cyberloafing & -.132 & -2.859 \\
\hline $\mathrm{R}^{2}=.026 ; \mathrm{F}=8.173$ & & &
\end{tabular}

Table 7 displays the results of hierarchical regression analysis to determine the effect of cyberloafing as a mediator between the dimensions of workload (psychological workload and physical workload) and organizational commitment. The results 
show that the strength of the relationship between the dimensions of workload (psychological workload and physical workload) and organizational commitment decreased after the inclusion of cyberloafing, but the relationship remained significant. This indicates that cyberloafing partially mediated the link between physical workload and organizational commitment, as well as psychological workload and organizational commitment. Therefore, hypothesis 6 and 7 were supported.

Table 7

The Mediating Effect of Cyberloafing between Workload Dimensions and organizational commitment

\begin{tabular}{llll}
\hline & Without Mediator & & \\
Independent variables & Std. beta & Independent variables & Mith Mediator \\
\hline Physical workload & .156 & Physical workload & Std. beta \\
Psychological workload & .526 & Psychological workload & .155 \\
\hline & & Cyberloafing & .512 \\
R $^{2}$ & .324 & $\mathrm{R}^{2}$ & .044 \\
Adj. R & .319 & Adj. R & .326 \\
F & 72.103 & F & .319 \\
Sig. & .001 & Sig. & 48.309 \\
\hline
\end{tabular}

\section{Discussion}

This study set out to examine the mediating role of cyberloafing on the relationship between workload and organization commitment among employees of a mining company in Jordan. The result indicated that cyberloafing partially mediated the relationship between workload and organization commitment in a positive direction, and the explanations for these results is that when the employees suffer from an enormous workload and excessive work pressure over a long period, they will use methods to alleviate this workload, including cyberloafing, and this affects their work commitment towards the organization. Similar findings were mentioned that cyberloafing is one of many ways for the employees to avoid such strain (Sawitri, 2012). Employees who undergo workload will engage in cyberloafing more often, specifically employees who constantly work under pressure. Similarly, Cahyadin (2012) reported that no matter how strong the employees' commitment to their organization, it will not reduce the cyberloafing behaviour of the employees. Thus, the higher the workload perceived by the employee, the higher the cyberloafing behaviour will show by the employees.

In line with the findings related to workload and organization commitment, the results showed that there is a positive significant relationship between the workload and organizational commitment, which supported by Viljoen and Rothmann (2009) and Alipour and Monfared (2014), who reported that work pressure and job stress contributed significantly to illnesses and low organisational commitment. Also, it was found that emotional exhaustion with work overload will reduce organizational commitment (Syailendra \& Soetjipto, 2017; Green \& Savin, 2013 ). When the relation between workload and cyberloafing was investigated in the present study, it was found that there is a statistical significance for the psychological workload, but not for the physical workload. This finding is in agreement with Liberman et al., (2011) who suggests that if the stress level of employees is high, he/she will delay the work by indulging in cyberloafing, which leads to reducing in work involvement and commitment. Şen et al. (2016) and Wan et al. (2014) also confirmed that the employees tend to engage in cyberloafing behaviour as a result of psychological workload. It is also proved that cyberloafing behaviour is a more reliable predictor of job burnout than cyberloafing activities (Aghaz \& Sheikh, 2016). Also confirmed that the employees might tend towards cyberloafing behaviour as a result of workload. (Şen et al., 2016; Wan et al., 2014). As for the relation between cyberloafing and organizational commitment, the result of the study demonstrated that there is a relation between cyberloafing and organization commitment. In line with this, Garrett dna Danziger (2008) suggested that by allowing employees to take a break from work and perform the cyberloafing behaviour will have a positive impact on work performance. Also, employees feel that surfing the internet while at work is generally a pleasurable activity that makes work more attractive (Lim \& Chen, 2012). It is also supported by Niaei et al. (2014) in his study which indicated that the cyberloafing behaviour of the employees and each of the dimensions of organizational commitment is related.

\section{Conclusion}

The present study has found that cyberloafing mediated the relationship between workload and organization commitment of workers in JPMC. The result has shown that there was a positive relationship between the workload, and organizational commitment, also between workload and cyberloafing and between cyberloafing and organization commitment. Since the study showed that there was a positive relationship between the workload and cyberloafing, appropriate strategies must be developed by the organization to reduce the workload and control employee orientation towards the use of cyberloafing, and focus on employing people who constitute low levels of occupational stress and high level of organizational commitment. The study found that the work environment and personal characteristics contributed to occupational stress and organizational commitment, thus, employees should be able to assess these factors efficiently and give each other support to improve performance. The organization also need to improve the workplace towards the stress-free environment, such as by providing good communication, recognition for excellent work and place to rest and socialize, which may reduce the psychological workload, and increase organizational commitment among their employees. The factors that contribute to the sources of the workload in the organization must be identified and organization must employ appropriate adaptation strategies to increase 
employee's commitment and performance such as provide clear and specific job descriptions, flexible work schedules, fair treatment, and a regular meeting between supervisors and their employees to discuss and solve their problems.

\section{References}

Adeoti, M. O., Shamsudin, F. M., \& Wan, C. Y. (2017). Workload, work pressure and interpersonal deviance in Academia: The mediating role of neutralization. International Journal of Human Resource Studies, 7(4), 1-22.

Aghaz, A., \& Sheikh, A. (2016). Computers in human behavior cyberloafing and job burnout: An investigation in the knowledge- intensive sector. Computers in Human Behavior, 62, 51-60.

Al-Hawajreh, K. M. (2012). Exploring the Relationship between Occupational Stress and Organizational Commitment among Nurses in Selected Jordanian Hospitals. Dirasat: Administrative Sciences, 161(719), 1-34.

Alipour, F., \& Kamaee Monfared, M. (2015). Examining the relationship between job stress and organizational commitment among nurses of hospitals. Journal of Patient Safety \& Quality Improvement, 3(4), 277-280.

Allen, N. J., \& Meyer, J. P. (2000). Construct validation in organizational behavior research: The case of organizational commitment. In Problems and solutions in human assessment (pp. 285-314).

Anandarajan, M., Simmers, C. A., \& D'Ovidio, R. (2011). Exploring the underlying structure of personal web usage in the workplace. Cyber psychology, behavior, and social networking, 14(10), 577-583.

Andersen, L. L., Fallentin, N., Thorsen, S. V., \& Holtermann, A. (2016). Physical workload and risk of long-term sickness absence in the general working population and among blue-collar workers: prospective cohort study with register follow-up. Occupational and Environmental Medicine, 73(4), 246-253.

Askew, K., Buckner, J. E., Taing, M. U., Ilie, A., Bauer, J. A., \& Coovert, M. D. (2014). Explaining cyberloafing: The role of the theory of planned behavior. Computers in Human Behavior, 36, 510-519.

Babbie, E. (1992). The Practice of Survey Research.

Baernholdt, M., Cox, K., \& Scully, K. (2010). Using clinical data to capture nurse workload: implications for staffing and safety. CIN: Computers, Informatics, Nursing, 28(4), 229-234.

Baljoon, R. A., Banjar, H. E., \& Banakhar, M. A. (2018). Nurses' work motivation and the factors affecting it: a scoping review. International Journal of Nursing \& Clinical Practices, 2018.

Cahyadin, M. (2012). The Moderation Effect of Commitment to Supervisor and Internet Expertise on Work Stressor and Employee Cyberloafing: The Study on Employee of Local Government of Surakarta. Journal of Indonesian Economy and Business, 27(2), 271-284.

Chun, Z. Y., \& Bock, G. W. (2006). Why employees do non-work-related computing: An investigation of factors affecting NWRC in a workplace. PACIS 2006 Proceedings, 79. 1259-1273.

Connelly, L. M. (2011). Cronbach's alpha. Medsurg Nursing, 20(1), 45-47.

Coker, B. L. (2013). Workplace internet leisure browsing. Human Performance, 26(2), 114-125.

Eastin, M. S., Glynn, C. J., \& Griffiths, R. P. (2007). Psychology of communication technology use in the workplace. CyberPsychology \& Behavior, 10(3), 436-443.

Freitas, V. H., Nakamura, F. Y., Miloski, B., Samulski, D., \& Bara-Filho, M. G. (2014). Sensitivity of physiological and psychological markers to training load intensification in volleyball players. Journal of sports science \& medicine, 13(3), 571.

Garrett, R. K., \& Danziger, J. N. (2008). Disaffection or expected outcomes: Understanding personal Internet during work. Journal of ComputerMediated Communication, 13(4), 937-958.

Green, L. V., Savin, S., \& Savva, N. (2013). "Nurse vendor problem": Personnel staffing in the presence of endogenous absenteeism. Management Science, 59(10), 2237-2256.

Hansson, G. Å., Balogh, I., Ohlsson, K., Granqvist, L., Nordander, C., Arvidsson, I., \& Skerfving, S. (2010). Physical workload in various types of work: Part II. Neck, shoulder and upper arm. International Journal of Industrial Ergonomics, 40(3), 267-281.

Hart, S. G. (2006, October). NASA-task load index (NASA-TLX); 20 years later. In Proceedings of the human factors and ergonomics society annual meeting (Vol. 50, No. 9, pp. 904-908). Sage CA: Los Angeles, CA: Sage publications.

Hashemi, S. M., Jusoh, J., Kiumarsi, S., \& Mohammadi, S. (2015). Exploring the role of stress on organizational commitment among employees in hospitality industry: the mediating role of job satisfaction. International Journal of Information Research and Review, 2(9), 1144-1150. https://doi.org/10.1007/s11886-015-0630-8

Hayes, L. J., O’Brien-Pallas, L., Duffield, C., Shamian, J., Buchan, J., Hughes, F., \& North, N. (2012). Nurse turnover: a literature review-an update. International journal of nursing studies, 49(7), 887-905.

Henle, C. A., \& Blanchard, A. L. (2008). The interaction of work stressors and organizational sanctions on cyberloafing. Journal of Managerial Issues, 383-400.

Herscovitch, L., \& Meyer, J. P. (2002). Commitment to organizational change: Extension of a three-component model. Journal of Applied Psychology, 87, 474-487.

Jain, A. K., Giga, S. I., \& Cooper, C. L. (2013). Stress, Health and Well-Being : The Mediating Role of Employee and Organizational Commitment. International Journal of Environmental Research and Public Health. 4907-4924.

Jamaluddin, H., Ahmad, Z., Alias, M., \& Simun, M. (2015). Personal Internet use: The use of personal mobile devices at the workplace. ProcediaSocial and Behavioural Sciences, 172, 495-502.

Kalyuga, S. (2011). Informing: A Cognitive Load Perspective. Informing Sci. Int. J. an Emerg. Transdiscipl. 14, $33-45$.

Khansa, L., Kuem, J., Siponen, M., \& Kim, S. S. (2017). To cyber loaf or not to cyber loaf: The impact of the announcement of formal organizational controls. Journal of Management Information Systems, 34(1), 141-176.

Kim, S. J., \& Byrne, S. (2011). Conceptualizing personal web usage in work contexts: A preliminary framework. Computers in Human Behavior, 27(6), 2271-2283.

Kivimäki, M., \& Kawachi, I. (2015). Work stress as a risk factor for cardiovascular disease. Current cardiology reports, $17(9), 74$.

Kowalski, C., Ommen, O., Driller, E., Ernstmann, N., Wirtz, M. A., Köhler, T., \& Pfaff, H. (2010). Burnout in nurses-the relationship between social capital in hospitals and emotional exhaustion. Journal of Clinical nursing, 19(11-12), 1654-1663.

Lee, K., Carswell, J. J., \& Allen, N. J. (2000). A meta-analytic review of occupational commitment: relations with person-and work-related variables. Journal of applied psychology, 85(5), 799.

Leiter, M. P., \& Maslach, C. (2009). Nurse turnover: the mediating role of burnout. Journal of Nursing Management, 17(3), 331-339. 
Liberman, B., Seidman, G., Mckenna, K. Y., \& Buffardi, L. E. (2011). Employee job attitudes and organizational characteristics as predictors of cyberloafing. Computers in Human behavior, 27(6), 2192-2199.

Lim, V. K. (2002). The IT way of loafing on the job: Cyberloafing, neutralizing and organizational justice. Journal of organizational behavior: the international journal of industrial, occupational and Organizational Psychology and Behavior, 23(5), 675-694.

Lim, V. K., \& Chen, D. J. (2012). Cyberloafing at the workplace: gain or drain on work?. Behaviour \& Information Technology, 31(4), $343-353$.

MacPhee, M., Dahinten, V. S., \& Havaei, F. (2017). The impact of heavy perceived nurse workloads on patient and nurse outcomes. Administrative Sciences, 7(1), 7.

Martins, J. T., Ribeiro, R. P., Bobroff, M. C. C., Marziale, M. H. P., Robazzi, M. L. D. C. C., \& Mendes, A. C. (2013). Meaning of workload on the view of cleaning professionals. Acta Paul Enform., 26(1), 63-70.

Meyer, J. P., Allen, N. J., \& Gellatly, I. R. (1990). Affective and continuance commitment to the organization: Evaluation of measures and analysis of concurrent and time-lagged relations. Journal of applied psychology, 75(6), 710.

Myny, D., Van Hecke, A., De Bacquer, D., Verhaeghe, S., Gobert, M., Defloor, T., \& Van Goubergen, D. (2012). Determining a set of measurable and relevant factors affecting nursing workload in the acute care hospital setting: a cross-sectional study. International journal of nursing studies, 49(4), 427-436.

Niaei, M., Peidaei, M. M., \& Nasiripour, A. A. (2014). The relation between staff cyberloafing and organizational commitment in organization of environmental protection. Kuwait Chapter of Arabian Journal of Business and Management Review, 33(2534), 1-13.

Nygren, T. E. (1991). Psychometric properties of subjective workload measurement techniques: Implications for their use in the assessment of perceived mental workload. Human factors, 33(1), 17-33.

Ozler, D. E., \& Polat, G. (2012). Cyberloafing phenomenon in organizations: Determinants and impacts. International Journal of business and government Studies, 4(2), 1-15.

Panaccio, A., \& Vandenberghe, C. (2012). Five-factor model of personality and organizational commitment: The mediating role of positive and negative affective states. Journal of vocational behavior, 80(3), 647-658.

Piotrowski. (2012). Cyberloafing: A Content Analysis of the Emerging Literature. Journal of Instructional Psychology, 39, $259-261$.

Rajah, R., \& Lim, V. K. (2011). Cyberloafing, Neutralization, And Organizational Citizenship Behavior. PACIS, 152, 24-40.

RuningSawitri, H. S. (2012). Role of internet experience in moderating influence of work stressor on cyberloafing. Procedia-Social and Behavioural Sciences, 57, 320-324.

Sage, M. A. (2015). Cyberloafing: A study of personality factors and organizational commitment as predictor variables of cyberloafing and perceived organizational acceptance.

Sawitri, H. S. R. (2012). Interaksi tekanan pekerjaan dan komitmen pada perilaku cyberloafing karyawan. Media Riset Bisnis \& Manajemen, 12(2), 91-107.

Şen, E., Tozlu, E., Ateşoğlu, H., \& Özdemir, A. (2016). The Effects of Work Stress on Cyberloafing Behavior in Higher Education Institutions. Eurasian Social Sciences Journal, 1, 523-535.

Sekaran, U. (2003). Towards a guide for novice research on research methodology: Review and proposed methods. Journal of Cases of Information Technology, 8(4), 24-35.

Siu, O. L. (2002). Occupational stressors and well-being among Chinese employees: The role of organisational commitment. Applied Psychology, 51(4), 527-544.

Sonnentag, S., \& Frese, M. (2012). Dynamic performance. Oxford library of psychology. The Oxford handbook of organizational psychology, 1, 548-575.

Svedberg, P., Mather, L., Bergström, G., Lindfors, P., \& Blom, V. (2018). Work-home interference, perceived total workload, and the risk of future sickness absence due to stress-related mental diagnoses among women and men: a prospective twin study. International Journal of Behavioral Medicine, 25(1), 103-111.

Syailendra, B., \& Soetjipto, B. W. (2017). IMPROVING WORK ENGAGEMENT OF GAS STATION OPERATOR WITH THE ROLE OF JOB RESOURCE, JOB DEMAND, AND JOB SATISFACTION. Jurnal Aplikasi Manajemen, 15(2), 310-319.

Taber, K. S. (2018). The use of Cronbach's alpha when developing and reporting research instruments in science education. Research in Science Education, 48(6), 1273-1296.

Tseng, M. L. (2011). Using a hybrid MCDM model to evaluate firm environmental knowledge management in uncertainty. Applied Soft Computing, $11(1), 1340-1352$.

Ugrin, J. C., Pearson, J. M., \& Odom, M. D. (2008). Profiling cyber-slackers in the workplace: Demographic, cultural, and workplace factors. Journal of Internet Commerce, 6(3), 75-89.

Usman, M., Javed, U., Shoukat, A., \& Bashir, N. A. (2019). Does meaningful work reduce cyberloafing? Important roles of affective commitment and leader-member exchange. Behaviour \& Information Technology, 1-15.

Verhaeghe, R., Vlerick, P., De Backer, G., Van Maele, G., \& Gemmel, P. (2008). Recurrent changes in the work environment, job resources and distress among nurses: A comparative cross-sectional survey. International Journal of Nursing Studies, 45(3), 382-392.

Viljoen, J. P., \& Rothmann, S. (2009). Occupational stress, ill health and organisational commitment of employees at a university of technology. SA Journal of Industrial Psychology, 35(1), 67-77.

Wan, H. C., Downey, L. A., \& Stough, C. (2014). Understanding non-work presenteeism: Relationships between emotional intelligence, boredom, procrastination and job stress. Personality and Individual Differences, 65, 86-90.

Winefield, A. H., Gillespie, N., Stough, C., Dua, J., Hapuarachchi, J., \& Boyd, C. (2003). Occupational stress in Australian university staff: Results from a national survey. International Journal of Stress Management, 10(1), 51.

Yeh, W. Y., Chiu, W. C., Chen, R. Y., Hu, P. Y., \& Tsai, D. M. (2019). A preliminary evaluation of psychological stress amongst workers in Taiwan: a cross-sectional survey. International journal of mental health systems, 13(1), 34.

Zhang, J., \& Zheng, W. (2009). How does satisfaction translate into performance? An examination of commitment and cultural values. Human Resource Development Quarterly, 20(3), 331-351.

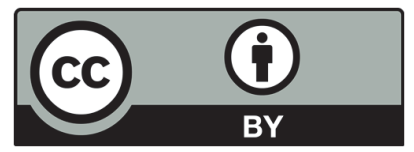

(C) 2020 by the authors; licensee Growing Science, Canada. This is an open access article distributed under the terms and conditions of the Creative Commons Attribution (CC-BY) license (http://creativecommons.org/licenses/by/4.0/). 